\title{
A magyar, a magyar jelnyelv és ami közötte van: kódváltás és kódkeverés a jelnyelvi tolmácsolásban
}

\author{
Ungár Nóra \\ E-mail:ungarnora@gmail.com
}

\begin{abstract}
Kivonat: A beszélt nyelvi tolmácsolás és a jelnyelvi tolmácsolás között az egyik legjelentősebb különbség, hogy a jelnyelvi tolmácsolás során nemcsak nyelvet, de modalitást is kell váltaniuk a tolmácsoknak: az auditív és vizuális csatornákat váltogatva kell észlelniük, a vokális és manuális csatornákat váltogatva pedig újraalkotniuk az üzeneteket. A jelnyelvi tolmács munkanyelvei közötti váltást nem csak a modalitás különbsége vagy a jelnyelvek változatai nehezítik. A munkanyelveket befolyásolja, hogy a jelnyelvet használó közösség mind a két munkanyelvet ismeri, és a nyelvi érintkezés nyomán köztes kontaktnyelveket is használ. A jelen szakirodalmi áttekintés célja, hogy számba vegye a jelnyelvi tolmácsok kétnyelvű célközönségének nyelvhasználatát és a tolmácsolás során használt nyelvek és kódok egymásra hatását a tolmácsolási stratégiák szempontjából.
\end{abstract}

Kulcsszavak: jelnyelvi tolmácsolás, munkanyelvek, bimodális bilingvalizmus, diglosszia, transzkódolás

\section{Bevezető}

A magyar jelnyelvről és a magyar jelnyelv használatáról hozott 2009. évi CXXV. törvény, amely elismeri a magyar jelnyelv státuszát, és biztosítja a jelnyelvet használó siket, nagyothalló és siketvak személyek jogát, hogy az állam által finanszírozott jelnyelvi tolmácsszolgáltatást igénybe vegyék, meghatározza azt is, hogy kik nyújthatják ezt a szolgáltatást. A szakmai végzettség elöírásán túl a jogszabály meghatározza a jelnyelvi tolmácsok által végzendö tolmácsolási feladatokat is.

A törvény meghatározása szerint a ,jelnyelvi tolmács: olyan személy, aki biztosítja az információ akadálymentes átadását siket, nagyothalló, siketvak és halló személyek között, a magyar jelnyelvről magyar nyelvre és magyar nyelvről magyar jelnyelvre tolmácsol, fordít, jelnyelvi szöveget írásba foglal, írótolmácsolási munkát

Hivatkozás: Ungár N. 2021. A magyar, a magyar jelnyelv és ami közötte van: kódváltás és kódkeverés a jelnyelvi tolmácsolásban. Forditástudomány 23. évf. 2. szám. 92-103. DOI: https://doi.org/10.35924/fordtud.23.2.5 
végez, orális tolmácsolást végez, illetve a Mellékletben meghatározott speciális kommunikációs rendszerek felhasználásával egyéb vizuális és taktilis kommunikációs formák között tolmácsol, fordít”. A melléklet pedig a következő speciális kommunikációs formákat határozza meg: taktilis jelnyelv, jelesített magyar nyelv, ujjábécé, daktil tenyérbe jelelése, magyar nyelvü beszéd vizualizálása, magyar nyelvü, hangzó beszéd írásba foglalása, Lorm-ábécé, tenyérbe írás, Braille-írás, Brailleírás taktilis formája, Tadoma vibrációs módszer (2009. évi CXXV. törvény).

Ahogy a jogszabály által támasztott elvárásokból kiderül, a jelnyelvi tolmácsszolgálatoknak és a jelnyelvi tolmácsoknak nem csak nyelvek közötti (interlingvális), de nyelven belüli (intralingvális), a nyelvek modalitásai közötti tolmácsolási feladatokat is el kell látniuk.

Nyelvek közötti tolmácsolásnak tekinthetjük a magyar nyelv és a magyar jelnyelv közötti átváltást, valamint a magyar nyelv és a jelesített magyar nyelv közötti tolmácsolást is attól függően, hogy a használt jelesített magyar nyelvváltozat a beszélt vagy a jelelt nyelvhez van-e közelebb. Szintén ide tartozik a magyar nyelv taktilis jelnyelvre fordítása.

Nyelven belüli tolmácsolásnak felelnek meg a magyar nyelv vizualizálását szolgáló, modalitások közötti átváltások (transzliteráció vagy transzkódolás): a hangzó magyar beszéd valós idejű írásba foglalása (feliratozás vagy írótolmácsolás) és a magyar nyelvü beszéd vizualizálása artikulációs tolmácsolással (melyet neveznek orális tolmácsolásnak is). Ugyanebbe a kategóriába tartoznak a hangzó beszéd tapintható érzékelését lehetővé tévő, modalitásbeli váltást eredményező technikák, például a tenyérbe írás, vagy a Tadoma vibrációs módszer, mely a szájról olvasás egy speciális, tapintható formája.

A hangzó beszéd vizualizálását vagy tapinthatóvá tételét nemcsak a modalitásbeli átváltás miatt tekinthetjük tolmácsolásnak, hanem azért is, mert a tolmács az átalakítás során a beszélt nyelvek közötti tolmácsoláshoz hasonlóan átalakítja a szöveget, kiszüri a redundanciákat, kiemeli a szövegkohéziós elemeket, és írott nyelvvé alakíthatja a szöveget.

A törvény mellékletében szereplő „kommunikációs formák” egy része valójában nem önálló tolmácsolási kód, hanem egy célnyelvi rendszer vagy nyelvváltozat eleme, egy-egy betűzési vagy írási technika, mint a Braille-írás, az ujjábécé, a daktil és a Lorm-ábécé.

Ahogy a jogszabály meghatározásában is tetten érhető a fogalmak közötti keveredés, úgy a szolgáltatás megvalósulásában, az egyéni tolmácsolási gyakorlatban is egymásba folynak a nyelvváltozatok, kódrendszerek, modalitások és technikák. Ez részben az ügyfelek egyéni nyelv- vagy kódhasználatából fakad, melyhez igazodik a tolmács, másrészt a szakmán belüli egységes meghatározások és gyakorlat hiányából, és jórészt abból, hogy nagyon keveset tudunk a felsorolt nyelvekről és nyelvváltozatokról.

Jelen tanulmány a jelnyelvi tolmácsok leggyakrabban használt munkanyelveit mutatja be, elsősorban az interlingvális tolmácsolásban használt nyelvváltozatokat és kódokat. 
A bevezetőt követő 2. rész a jelnyelvet használó közösség kétnyelvüségével és a siket és nagyothalló személyek által használt nyelvváltozatokkal foglalkozik. A 3. rész bemutatja a kétnyelvü közösség nyelvei közötti érintkezés hatásait a tolmácsolási nyelvek használatára és a tolmácsolási stratégiákra. A 4. rész a tolmácsolást igényebevők elvárásait, az 5., befejező rész pedig a tolmácsok kompetenciájának korlátait vizsgálja meg.

\section{A jelnyelvhasználó, siket és nagyothalló közösség kétnyelvűsége}

A jelnyelveket és a jelnyelvi tolmácsolást kutató tudományos közösségen belül általános konszenzus, hogy a jelnyelvet használó siket és nagyothalló személyek kétnyelvüek. A vizsgált közösségek tagjai a világ minden pontján ismerik és használják a többségi társadalom (hangzó) nyelvét és saját jelnyelvüket is. A siket jelnyelvhasználó közösség kétnyelvüségét bimodális kétnyelvüségként határozzák meg, mivel a két nyelv eltérő csatornákat (auditív-verbális és vizuális-manuális) használ az értéshez és a produkcióhoz. A többségi beszélt nyelv használatára többnyire az írásbeliség jellemző, bár a siket és nagyothalló személyek többsége képes a hangos beszédre, és szájról olvasás útján értheti a hangosbeszédet is. A nyelvhasználók egyéni szintjén szinte soha nem beszélhetünk kiegyenlített bilingvalizmusról, az egyéni hallási képességek, a nyelvek elsajátításának ideje, helye és a nyelvhasználat kontextusai befolyásolják, hogy egy siket vagy nagyothalló egyén milyen nyelvi és kulturális kompetenciákra tesz szert.

A jelnyelvhasználó közösségre és az egyénekre is jellemző a diglosszia, mivel a többségi nyelvet és a jelnyelvet elkülönülő kontextusokban használják, és a két nyelv közösségen belüli vagy az egyén által érzékelt presztízse is eltérő lehet. Ugyanakkor az egyének nyelvhasználatában megjelenik a két nyelv érintkezéséből fakadó kódváltás, kódkeverés és a kontaktkódok is (Emmorey et al. 2005, Bartha et al. 2016, Romanek 2017).

A tolmácsolás szempontjából a magyar siket és nagyothalló közösség által használt nyelvek és nyelvváltozatok közül a magyar jelnyelv és a magyar nyelvvel való érintkezéséből eredeztethető jelesített magyar nyelv a leginkább meghatározó.

A jelnyelvek, köztük a magyar jelnyelv is, önálló szókinccsel és nyelvtannal rendelkező, természetes nyelvek, ahol a jelentést a kézjelek és a nem-manuális elemek (mimika, testtartás, gesztusok) együttesen fejezik ki (Sandler és LilloMartin 2006).

A jelnyelv és a beszélt nyelv között elhelyezkedő pidzsin jelesített nyelveket nagyon nehéz pontosan behatárolni, és jellemzően a két érintkező nyelv között egy kontinuumként szokták meghatározni a jelelt nyelvek számtalan változatát, melyek eltérő távolságra lehetnek a beszélt, illetve a jelelt nyelvektöl, azonban ezt a meghatározást is gyakran vitatják (Lucas és Valli 1992).

A jelesített nyelvekre jellemző, hogy a közlések a beszélt nyelv nyelvtani szerkezetét követik, a szavakat a jelnyelvi jelekkel kifejezve. Szintén jellemző az arti- 
kuláció és a betüzés erőteljesebb használata. Ugyanakkor nem egyértelmüen csak a magyar nyelv vizualizált változatáról van szó, a kontaktváltozatokban megjelenhetnek a jelnyelvekre jellemző párhuzamos közlések, téri nyelvtani szerkezetek és más elemek, például a térpontok és a hozzájuk kapcsolódó utalások, a változó tövű igék vagy a helyettesítő kézformák is (Valli és Lucas 1992). A kódkeverés mértéke és a kontaktkódok használata az egyéni beszélők stílusa, nyelvi kompetenciája szerint széles spektrumon változhat (Emmorey et al. 2005, Bartha et al. 2016, Romanek 2017).

A következő rész azt mutatja be, hogy a jelnyelvhasználó közösség által használt nyelvek és azok egymásra hatása milyen módon befolyásolja a jelnyelvi tolmácsolást és a tolmács munkanyelveit.

\section{A bilingvalizmus és a diglosszia megjelenése a tolmácsolásban}

\subsection{Bimodális tolmácsolás}

A jelnyelvi tolmácsolás kutatása során, legyen szó a stratégiákról, a tolmácsolási irányokról vagy a munkanyelvek viszonyáról, mindig kiemelt szempont az érintett nyelvek, a beszélt nyelv és a jelnyelv modalitásbeli különbsége. A beszélt nyelvi tolmácsok munkanyelveinek észlelése, érzékelése és produkciója is azonos modalitásban történik, vagyis hallás útján észlelik és a hangképző szervekkel produkálják. A jelnyelvi tolmácsok munkanyelveinek azonban eltérő a modalitása: a jelnyelv észlelése látás útján, produkciója pedig a kéz, az arc és a test mozgásával valósul meg. A jelnyelvi tolmácsolás tehát különbözik a beszélt nyelvi tolmácsolástól a modalitásokban, a tolmácsolási módokban és a tolmácsolási irányokban is. (Valli és Lucas 1992, Nicodemus és Emmorey 2013).

A munkanyelvek közötti modalitásbeli különbség nemcsak eltérő észlelést és kivitelezést jelent, hanem a két nyelv közléseinek eltérő felépítését és időbeli megjelenését. A jelnyelvi közlések a beszélt nyelvi közlésekkel ellentétben nemcsak lineárisan követik egymást, hanem párhuzamosan, egyidejüleg is megjelenhetnek a jelnyelvi artikulációban részt vevő testrészeken, a lexikai elemeket közvetítő kézformákon túl a testtartás, a fej, a karok, vállak mozgásában és az arckifejezésekben (szemöldök, tekintet, száj stb. mozgása). A jelnyelv vizuális, téri eszközeiböl adódóan is a nyelv sokkal több vizuális információt kódol, melyek a beszélt nyelvekben egyáltalán nem jelennek meg, azonban a tolmácsnak a beszélt és a jelnyelv közléseinek megfeleltetésekor ezeket az információkat hozzá kell adnia a célnyelvi jelnyelvi közléshez, vagy ki kell vennie a célnyelvi beszélt nyelvi közlésböl.

A modalitásbeli váltás és a jelnyelvek - a beszélt nyelvekhez képest - korlátozott szókincse megerösíti azt a feltételezést, hogy a jelnyelvi tolmácsolás esetében a használt nyelvpár közötti teljes átalakítás nagyobb kognitív terhelést jelent, mintha egymáshoz közelebb álló, például rokon beszélt nyelvek között kell közvetítenie a tolmácsnak. Egy azonos forrásnyelvi angol szöveg két „rokon” beszélt nyelvre: 
franciára és németre, egy távolabbi beszélt nyelvre: japánra és amerikai jelnyelvre tolmácsolt változatait összehasonlító kutatás (Swabey et al. 2016) a tolmácsok által vétett hibákat és kihagyásokat alapul véve igazolta, hogy a munkanyelvek közötti távolság valóban nagyobb kognitív terhelést jelent a tolmácsolás során, amikor a célnyelvi szöveget kell megfogalmaznia a tolmácsnak. Ugyanakkor a célnyelvi ekvivalensek hiánya nem eredményezett különbséget a célnyelvi szövegek lexikai változatossága vagy az üzenet pontos közvetítése szempontjából.

A beszélt nyelvek között tolmácsoló tolmácsoknak is nehéz alkalmanként megfelelö ekvivalenst találni, de a jelnyelvi tolmácsoknak azt is el kell dönteniük, hogy milyen vizuális információt adjanak hozzá vagy hagyjanak ki az üzenetből a tolmácsolás során, és ez mindenképpen befolyásolja a közvetített üzenet tartalmát is (Napier 2015).

Az üzenetek kiegészítése azonban fontos ahhoz, hogy a beszélt nyelvi szöveget a tolmács a jelnyelvi normáinak megfelelve, kulturálisan megfeleltetve közvetítse. Ez is lehet az oka annak, hogy a jelnyelvi tolmácsolás kapcsán gyakran felmerül kérdésként, hogy mit tekinthetünk „hü” fordításnak. Mikor beszélhetünk szó szerinti vagy értelem szerinti fordításról, és mit tekinthetünk nyelvileg megfelelő vagy pontos tolmácsolásnak? A jelnyelvi tolmácsolás esetében ezt a jelnyelvet használó közösség által is használt nyelvi kódok közötti választás is meghatározza.

A befogadók a jelnyelvi tolmácsolást nem csak aszerint értékelik, hogy menynyire pontosan sikerült átadni a forrásnyelvi közlés tartalmát, de aszerint is, hogy a jelnyelvi tolmács fordítása mennyire követte a jelnyelv nyelvtani szerkezetét, és mennyire tudta a normáknak megfelelően alkalmazni a nyelvek közötti transzferencia, a kódváltás, kódkeverés és a lexikai kölcsönzés eszközeit. Mindezeket elsősorban a tolmácsolás témája, a tolmácsolási helyzet és a résztvevők határozzák meg (Davis 1989, 1990). A következő rész a jelnyelv és a kontaktnyelv használatát mutatja be a jelnyelvi tolmácsolásban.

\subsection{Nyelvek közötti transzferencia és interferencia a jelnyelvi tolmácsolásban}

Davis $(1989,1990)$ az átvitel (transference) és az interferencia (interference) különbségeit vizsgálta az angolról amerikai jelnyelvre (ASL) tolmácsolásban, a kódváltásra, kódkeverésre és a lexikai kölcsönzésekre keresve példákat.

Meghatározása szerint ha a kódváltás és kódkeverés alkalmanként és jelöletlenül fordul elő a tolmácsolásban, tehát az angol nyelvi formák megjelenése az ASL célnyelvi szövegben befolyásolja az üzenet tartalmát, akkor interferenciának tekinthetjük, és az oka valószínüleg a tolmács gyengébb célnyelvi kompetenciája. Ha a tolmács az angol nyelvi formákat vizuálisan kódolja és jelöli a célnyelvi ASL szövegben, akkor átvitelnek (transzferenciának) tekinthetjük, tudatos stratégiának, mellyel a tolmács a két nyelv közötti különbségeket hidalja át, és tisztázza a kétértelmüségeket. 
Davis megállapítása szerint a beszélt nyelv három jellemző módon jelenik meg a tolmácsolt célnyelvi szövegben: 1) angol nyelvü szavak artikulációjaként az ASL jeleinek kivitelezésével egy időben, 2) ujjábécével betüzött szavak beszúrásával egy ASL jel előtt, 3) és egy adott angol szó betüzött vagy jelelt formájának ASL jellel való jelölésével. Az első esetben nyelvi kölcsönzésröl vagy egy már a jelnyelvben lexikalizálódott jel és artikuláció kombinációjának használatáról van szó, amely elsősorban jelentéskonkretizáló funkciót tölt be a nyelvben. A második esetben a betüzött angol szavak, kifejezések beszúrása többféle formában is előfordulhat. Lehet szó egy már jövevényszóként meghonosodott korábbi lexikai kölcsönzés használatáról, ezekben az esetekben a kifejezés betüzése már elnagyolt, és ,,jelként" fonológiailag illeszkedik a jelnyelvi szerkezetbe. Lehet egyszeri kölcsönzés, a tolmácsolás során felbukkanó új kifejezés transzliterációja, mely később lexikalizálódhat a jelnyelvben, és végül előfordulhatnak olyan betüzések, ahol ténylegesen egy beszélt nyelvi elem, például név megjelenítése a cél. Végül a harmadik esetben angol nyelvi fordulatok jelennek meg jelnyelvi formában, például a „hogy úgy mondjam" értelmü, idézőjelet utánzó jel használatával. Az átvitelek célja ezekben az esetekben a célnyelvi közlésben a két nyelv közötti különbségek áthidalása és a célnyelvi szöveg gazdagítása. Az átvitelek használatát befolyásolják a résztvevők, a téma és a tolmácsolási helyzet is.

A beszélt nyelv és a jelnyelv közötti interferencia a tolmácsolásban Davis (1989, 1990) meghatározása szerint a stratégiai átvitelekkel szemben éppen a nyelvek közötti jelöletlen, sporadikus váltást jelenti. Ez a leggyakrabban a kontaktnyelv mint célnyelv használatában, illetve a jelnyelv és a jelesített nyelv közötti kódváltásokban érhetö tetten.

A transzkódolás vagy calque a beszélt nyelvi tolmácsolásban is megjelenik a tolmácsolási stratégiák között mint mentőstratégia, melyet akkor alkalmaz a tolmács, ha nem sikerül megragadnia az eredeti közlés átfogó értelmét, ezért az eredeti szöveg felszíni struktúrájához tapadva, szóról szóra tolmácsol (Gile 1995; Láng 2002).

Ha nem tudatos célnyelvi kódválasztásról van szó (erről még szó lesz ebben a részben), akkor a jelnyelvi tolmácsolás esetében is mentőstratégiaként müködik transzkódolás, a jelesített nyelvre váltás. A stratégia alkalmazását indokolhatja, hogy a forrásnyelvi szöveg nehezen értelmezhető: szakszöveg, túl sok speciális kifejezést, nevet, számot tartalmaz, túl gyors a beszédtempó, a tolmács nem érti jól a beszélöt, vagy a tolmácsolást nehezítő más körülmény miatt ezzel a stratégiával tudja a kapacitásait kiegyenlíteni.

A beszélt nyelvi tolmácsokkal végzett felmérésekkel ellentétben a jelnyelvi tolmácsok többsége szívesebben tolmácsol az első nyelvéről (a beszélt nyelvről) a második nyelvére (a jelnyelvre). A jelnyelvi tolmácsok nyelvi kompetenciája és a tolmácsolás irányával kapcsolatos preferenciája közötti összefüggések vizsgálatakor Nicodemus és Emmorey (2015) azt találta, hogy ez nem feltétlenül magyarázható a tolmácsok nyelvi kompetenciájával vagy az objektív teljesítményével. Kutatásukból az derült ki, hogy a preferencia ellenére a kezdő tolmácsok sokkal jobb 
teljesítményt nyújtottak, amikor jelnyelvről fordítottak beszélt nyelvre (az első nyelvükre), míg a gyakorlott tolmácsok esetében nem volt jelentős különbség a két irány között teljesítmény alapján. A kutatók három, a jelnyelv modalitásából adódó lehetséges magyarázatot találtak arra, hogy miért szeretnek mégis a jelnyelvi tolmácsok inkább jelnyelvre tolmácsolni: az ujjábécé alkalmazása és a transzkódolás két olyan stratégia, amely kisegíti a tolmácsot, azzal együtt is, hogy nyelvtanilag helytelen vagy a befogadó által nem értelmezhető szöveget eredményez, mégis úgy érezheti a tolmács, hogy sikeresen „megoldotta” a tolmácsolási feladatot. Ezeket a stratégiákat, technikákat a másik irányban - jelnyelvről beszélt nyelvre tolmácsoláskor - nem tudják alkalmazni, és ez indokolhatja, hogy a gyakorlott tolmácsok között is jellemzö, hogy jobban szeretnek jelnyelvre tolmácsolni. A harmadik lehetséges ok, hogy a beszélőkkel szemben a jelnyelvhasználók nem kapnak közvetlen érzékelhető visszacsatolást a produkciójukról, látni nem látják a saját jelelésüket, csak torzított formában, viszont a szomatoszenzoros visszajelzés, a testérzet értékelése lassabban alakulhat ki a jelnyelvet második nyelvként elsajátítóknál. Ezért a kezdő tolmácsoknak hamis képük lehet a saját produkciós teljesítményükről.

A betüzés és a transzkódolás szó- vagy kifejezésszinten alkalmazható nyelvi stratégiaként a jelnyelvi tolmácsolásban, ha a tolmács nem tudja egy beszélt nyelvi kifejezés jelnyelvi jelét, vagy ha a kifejezésnek nincs jelnyelvi megfelelöje. Azonban ezek a stratégiák gyakran nem sikeresek, mert az ügyfél nem ismeri a beszélt nyelvi kifejezést, vagy a betüzött, artikulált szó nyelvtanilag nem illeszkedik megfelelően a jelnyelvi szerkezetbe. A nagyobb szövegegységek transzkódolása, azaz a jelelt nyelv használata a tolmácsolási helyzet nehézségeit kompenzáló stratégiaként szintén olyan szó szerinti fordítást eredményezhet, amely nem követi a jelnyelv morfológiáját, hiányoznak belőle a szintaktikai jelölők, és nyelvileg helytelen, a befogadó számára értelmezhetetlen jelnyelvi közlés (Nicodemus és Emmorey 2015; Moody 2011).

A jelesített nyelv mint célnyelv használata ráirányíthatja a figyelmet a tolmács gyenge nyelvi kompetenciájára, és a kód választása miatt sok kritika érheti a tolmácsokat a befogadók részéröl, különösen akkor, ha a tolmácsolás nyelvileg nem igazodik sem a tolmácsolási kontextushoz, sem a közönség igényeihez vagy nyelvi normáihoz.

\subsection{Transzkódolás, jelesített nyelvre tolmácsolás}

A jelesített nyelvre tolmácsolás tudatos célnyelvválasztás esetén több, mint az elhangzó szöveg vizualizálása. Winston (1989) kutatása során arra jutott, a transzliteráció az ASL és a beszélt angol jellemzőinek összetett kombinációja. A transzliteráció célja, hogy a jelnyelv lexikális elemeinek segítségével a beszélt nyelvhez közelebb álló szöveget hozzon létre, azonban az eredménye a beszélt és a jelnyelv szempontjából is befejezetlen üzenet. Ahhoz, hogy ez a vizuálisan kevésbé befogadható formátum világosabb és érthetőbb legyen, célszerü a jelnyelv eszköztárából 
többet kölcsönözni. Ezek az eszközök a tudatos jelválasztás, a kiegészítés, a kihagyás, az átstrukturálás és az artikuláció. A tudatos jelválasztásnál a tolmács a többjelentésü beszélt nyelvi szavak megjelenítésekor az adott kontextusnak megfelelö jelentésű jelnyelvi kifejezést választja ki. A kiegészítés jelentheti azt, hogy egy szó szerint fordított összetett kifejezést kiegészít a jelnyelvi megfelelővel, hogy egyértelmüsítse a jelentést, vagy a jelnyelv térpontjainak segítségével tisztázza a közlés alanyát, tárgyát, arckifejezés hozzáadásával közvetíti a hanggal közvetített nonverbális közléseket, például a hangsúlyt. A kihagyás elsősorban a beszéd redundáns, a jelentés szempontjából nem releváns elemeinek vagy a jelnyelvböl kölcsönzött elemekkel már megjelenített jelentésü kopulák, toldalékok, ragok elhagyását jelenti. Az átalakítás a nyelvi szerkezetek áthelyezését vagy behelyettesítését jelenti. Végül az artikuláció a transzkódolás során a jelválasztás szempontjából kap fontos szerepet, mert egyértelmüsíti, hogy az adott jel melyik jelentésében szerepel, megjelenítve a forrásnyelvben szereplö kifejezést. Winston később azt is vizsgálta (Winston 2003), hogy a jelnyelvből kölcsönzött, a tolmácsolt szöveg témahatárait jelölő mely prozódiai elemek segíthetik a jelesített nyelvre transzkódolt szöveg megértését.

A transzkódolás vagy jelesített nyelvre tolmácsolás elfogadott a siket jelnyelvhasználók között, sőt előfordul, hogy ügyfelek kimondottan ezt kérik a tolmácstól a saját nyelvtudásukra vagy képzettségükre alapozva, vagy azért, mert a téma megértését esetükben ez a nyelvi kód segíti. A beszélt nyelvet követő jelelés elfogadottságát az is magyarázza, hogy a siket közösségekben sokáig ezt a nyelvváltozatot a jelnyelvnél kifinomultabbnak, magasabb rendünek tekintették (Padden és Humphries 1988). Bár a transzkódolás gyakran nem olyan könnyen értelmezhető az ügyfelek számára, mint a jelnyelvre tolmácsolás, a tolmácsok mégis gyakran használják. Ennek az is az oka, hogy a siket ügyfelek ritkán adnak visszajelzést a nekik nyújtott tolmácsolás minőségéről vagy az elégedettségükről (Nicodemus és Emmorey 2015).

Sok tolmácsolási helyzetre jellemzö, hogy a siket és nagyothalló közönség megfelelő szinten bírja az írott vagy beszélt forrásnyelvet, és tolmácsolásra tulajdonképpen nem azért van szükség, mert a siket közönség nem érti a beszélt nyelvet, hanem mert nem hallja azt. Feltételezve, hogy a közönség kétnyelvü, a tolmácsnak lehetősége van arra is, hogy a beszélt (forrás-) nyelv szavait, kifejezéseit, szintaxisát vizuálisan megjelenítse, kódolja ujjábécé vagy a jelnyelv jelei segítségével (Davis 1990).

A jelesített nyelv vagy kevert kód használatát sokszor a tolmácsolási helyzetben használt beszélt nyelvi regiszter is motiválhatja. A jelnyelvekre általában igaz a beszélt nyelveknek megfeleltethető regiszterek hiánya, amit részben alátámaszt az, amit jelnyelvi közösségek diglossziájáról tudunk. A jelnyelvhasználók jellemzően egymás között használják a tiszta jelnyelvi változatokat informális helyezetekben vagy a siket közösségben, és a regisztereket nem az eltérő szókincs, hanem a prozódia (ritmus, tempó stb.) különbözteti meg egymástól. Ismeretlen közönséghez beszélve vagy szokatlan, formális helyzetekben a kevert nyelv használata válik formális regiszterré (Crasborn 2009; Stone 2010). 


\section{Az ügyfelek elvárásai}

A jelnyelv kiemelt értéket képvisel a siket közösség számára: a siket kultúra legfontosabb eleme, és nagyon fontos identitásmeghatározó szerepet tölt be (Romanek 2017).

Várható lenne, hogy a jelnyelvet elsődleges nyelvükként használó ügyfelek ezt részesítsék előnyben a tolmácsolás során is. A kulturális, nyelvi identitás mellett azonban fontos szerepet játszik a tolmácsolást igénybe vevő nyelvi kompetenciája is.

A siket jelnyelvhasználóknak jellemzően alacsonyabb a beszélt nyelvi kompetenciája, és a vizuális kódolás a jelnyelv használatának kedvez. A jelesített magyar megértéséhez, vagy akár a szájról olvasáshoz kellően magas magyar nyelvi kompetenciával kell rendelkeznie a befogadónak, így ennek a kódnak a használata inkább a nagyothallókra jellemzö (Henger és Kovács 2005).

A transzliterációt vagy a jelesített nyelv használatát azonban sok körülmény indokolhatja az ügyfelek szempontjából, és gyakrabban várják el a tolmácstól, hogy ezt a kódot használja (Moody 2011).

\subsection{Szó szerinti tolmácsolást igénylő tolmácsolási helyzetek}

A bírósági tolmácsolási helyezetekben többnyire a csatornamodell alapján működő közvetítőknek tekintik a tolmácsokat, és elvárás a bírók részéröl, hogy mindent, ami elhangzik, szó szerint tolmácsoljanak, különös tekintettel a ,jogra”, melyet csak a jogászok értelmezhetnek a tárgyalóteremben. Minden szónak jelentősége van, és a résztvevők kijelentéseit nem lehet leegyszerüsíteni. Azonban több kutatás is alátámasztotta, hogy a tárgyalóteremben is elvárt a kulturális mediáció, és a tolmácsok szerepe gyakran meghaladja a csatornamodellt (Moody 2011).

Szakmai témájú konferenciák esetében elvárás lehet a jelnyelvhasználó ügyfelek részéről, hogy a tolmács szó szerint tolmácsoljon, mivel a tolmácstól nem elvárható, hogy az ügyfelekkel azonos szinten ismerje a szakzsargont, ugyanakkor számukra fontos az elhangzottak tartalma. A bíróságon, konferenciákon vagy a médiában tolmácsoló tolmácsok elsősorban az információ továbbítását érzik feladatuknak, ezekben a helyzetekben az üzenet kiegészítése vagy magyarázata leereszkedő vagy kockázatos is lehet (Moody 2011).

Ezekre a helyezetekre jellemző az is, hogy jelentősen lerövidül a követési idő, mivel a tolmács nehezen tárolja a munkamemóriájában az általa nem értelmezhetö információkat. A követési idő rövidülése szintén motiválja a transzkódolást. Akár nem szakmai tartalmú szöveg tolmácsolásakor is előfordul, hogy ha a forrásnyelvi szöveg túl sok nevet vagy számot tartalmaz, akkor a tolmácsok a jelesített nyelv használatára váltanak (Moody 2011).

Közösségi tolmácsolási helyzetekben is jellemzö, hogy szakmai tárgyú, például munkahelyi tolmácsolási helyzetekben az ügyfelek „felszíni tolmácsolást” (surface rendering), nem a forrásszöveg értelmének fordítását kérik, mert a tol- 
mács nem ismeri sem a kontextust, sem a munkatársak számára egyértelmű szakmai tartalmat olyan mélységben, hogy értelmezni tudja az elhangzottakat. A siket ügyfél azonban a mindennapokban a beszélt nyelven, írásban (e-mailben, csetben) kommunikál a munkatársakkal, így számára a transzliteráció lehetővé teszi, hogy mélységében értelmezze a kontextus alapján az elhangzottakat (Stone 2010).

A transzliterációt gyakran azért is választják a beszélt és a jelnyelvet egyformán magas szinten bíró ügyfelek, mert a tartalom mellett számukra fontos a forma közvetítése is. Ez az igény megjelenhet olyan jelnyelvhasználó ügyfelek részéröl, akik a halló félnél magasabb vagy egyenlő státuszban vannak, mondjuk egy szervezeten belül vagy akár kormányzati pozícióban. Ezek az ügyfelek jól ismerik a beszélt nyelvi és kulturális normákat, és kíváncsiak lehetnek arra, hogy pontosan hogyan fejezik ki magukat a velük érintkező halló beszélők. Előfordulhat az is, hogy a siket és nagyothalló ügyfelek nem bíznak a tolmács jelnyelvi tudásában, ezért inkább maguk végzik el a jelesített nyelvű szöveg értelmezését, tolmácsolását (Moody 2011).

Gyakran visszatérö kérdés, hogy milyen nyelven közvetítsen a tolmács oktatási helyzetekben, ahol a felhasználóknak még gyakran nincsenek világos elvárásai a tolmácsolással kapcsolatban. Sok szakértő egyértelmüen az értelem szerinti tolmácsolást támogatja, hiszen fontos, hogy az integráltan, halló osztályban tanuló siket vagy nagyothalló diák értse a tananyagot. Ugyanakkor az osztályteremben nem a tolmács feladata, hogy kiegészítse vagy magyarázza a tanár által elmondottakat, és a tanulóktól elvárt, hogy ismerjék, értsék és használják a beszélt nyelv tantárgyhoz kapcsolódó fogalmait és szókincsét (Moody 2011).

Közösségi tolmácsolási helyzetekben a tolmácsok szerepe sokkal inkább eltolódik a kulturálisközvetítö-modell felé, és az ügyfelek elvárják a tolmács együttmüködését és mediációs szerepvállalását a tolmácsolási helyzetben, amely megkönnyíti a tolmácsolt szituációban részt vevők számára, hogy minél jobban megértsék egymást. Ehhez az elváráshoz illeszkedik az értelem szerinti, a jelnyelvi és kulturális normáknak megfelelő tolmácsolás, ami kellemes a befogadó számára (Moody 2011).

\section{A tolmácsok nyelvi kompetenciája}

A jelnyelvi tolmácsok számára a siket és nagyothalló közösség nyelvi sokféleségének sajátosságai közül a kevert kódok számtalan formája okozza a legnagyobb nehézséget. A kódok keverésének mértéke és módja lehet teljesen egyéni, mivel általában nincsenek tisztán meghatározott vagy elkülöníthető nyelvváltozatok, és az egyén preferenciáján és nyelvi kompetenciáján múlik, hogy a spektrum két végén elhelyezkedő jelnyelv és jelesített beszélt nyelv között milyen köztes, kevert kódot használ (Crasborn 2009).

A tolmácsok számára a kódok közötti váltást vagy a megfelelő kevert kód kiválasztását nehezíti, ha nem ismeri az ügyfelét, akinek tolmácsol, a lehetőségeit 
korlátozza a saját nyelvtudása, és a tolmácsolási helyzetben résztvevőhöz való alkalmazkodás. Előfordul, hogy a jelnyelvet felnőttként elsajátító jelnyelvi tolmácsok a tolmácsolási helyzetben ösztönösen igazodnak a beszélt nyelvi (forrásnyelvi) közlöhöz, így a célnyelvi produkciójuk is inkább a beszélt nyelv felé hajló kontaktkód lesz. Ugyanez az alkalmazkodás sokszor a jelnyelvhasználó résztvevők nyelvhasználatában is megfigyelhető, vagyis egy tolmácsolási helyzetben az általuk használt jelnyelvi kódot is befolyásolja a beszélt nyelv (Crasborn 2009).

A tolmács célnyelvválasztását befolyásolja a saját kompetenciája és a tolmácsolási helyzetről és a befogadókról rendelkezésére álló információ. A döntést nehezíti, hogy nincs objektív viszonyítási a pont a nyelvváltozatok értékeléséhez. Sem a jelnyelvhasználó közösség, sem a jelnyelvet kutatók nem tudják megítélni, hogy mi számít tisztán jelnyelvi közlésnek, és mi az, ami már kevert kód. A magyar szakmai közösségben pedig nincs konszenzus arról, hogy például olyan helyzetekben, amikor nincs konkrét ügyfél, akihez igazodni lehet (például a médiatolmácsolások esetében), akkor melyik kód az, ami megfelel a nyelvhasználói normának, és minél több ember számára teszi elérhetővé, érthetővé a közvetített üzenetet.

\section{Irodalom}

2009. évi CXXV. törvény a magyar jelnyelvröl és a magyar jelnyelv használatáról. Internetes megjelenés: https://net.jogtar.hu/jogszabaly?docid=a0900125.tv\#lbj0idffde

Bartha Cs., Holecz M., Romanek P. Z. 2016. Bimodális kétnyelvűség, nyelvi szociokulturális változatosság és hozzáférés: A JelEsély modell eredményei és távlatai. In: Bartha Cs. (szerk.) A többnyelvüség dimenziói: Terek, kontextusok, kutatási távlatok. Budapest: Akadémiai Kiadó. 337-370.

Crasborn, O., Bloem, T. 2009. Linguistic Variation as a Challenge for Sign Language Interpreters and Sign Language Interpreter Education in the Netherlands. In: Napier, J. (ed.) International Perspectives on Sign Language Interpreting. Washington D.C.: Gallaudet University Press. 77-95.

Davis, J. 1989. Distinguishing Language Contact Phenomena in ASL Interpretation. In: Lucas, C. (ed.) The Sociolinguistics of the Deaf Community. Academic Press. 85-102. https://doi.org/10.1016/B978-0-12-458045-9.50010-0

Davis, J. 1990. Linguistic Transference and Interference: Interpreting Between English and ASL. In: Lucas, C. (ed.) Sign Language Research: Theoretical Issues. Washington D.C.: Gallaudet University Press. 308-321.

Emmorey, K., Borinstein, H., Thompson, R. 2005. Bimodal Bilingualism: Code-blending between Spoken English and American Sign Language. Proceedings of the 4th International Symposium on Bilingualism.

Gile, D. 1995/2009. Basic Concepts and Models for Interpreter and Translator Training. Amsterdam, Philadelphia: John Benjamins.

Hattyár H. 2008. A magyarországi siketek nyelvelsajátitásának és nyelvhasználatának szociolingvisztikai vizsgálata. Doktori disszertáció. Budapest: ELTE. Internetes megjelenés: http://doktori.btk.elte.hu/lingv/hattyar/diss_nem.pdf 
Henger K., Kovács Zs. 2005. A jelnyelvi tolmácsolás alapismeretei. Jelnyelvi Tolmácsképzés sorozat. Budapest: Fogyatékosok Esélye Közalapítvány.

Láng Zs. 2002. Tolmácsolás felsőfokon. Budapest: Scholastica.

Lucas, C., Valli, C. 1992. Language Contact in the American Deaf Community. San Diego: Academic Press.

Moody, B. 2011. What is a Faithful Interpretation? Journal of Interpretation Vol. 21. No. 1. Internetes megjelenés: http://digitalcommons.unf.edu/joi/vol21/iss1/4

Napier, J. 2015. Comparing signed and spoken language interpreting. In: Mikkelson, H., Jourdinais, R. (eds) The Routledge Handbook of Interpreting. Routledge. 129-143.

Nicodemus, B., Emmorey, K. 2013. Direction asymmetries in spoken and signed language interpreting. Bilingualism: Language and Cognition. Vol. 16. No. 3. 624-636. https:// doi.org/10.1017/S1366728912000521

Nicodemus, B., Emmorey, K. 2015. Directionality in ASL-English interpreting: Accuracy and articulation quality in L1 and L2. Interpreting. Vol. 17. No. 2. 145-166. https:// doi.org/10.1075/intp.17.2.01nic

Padden, C., Humphries, T. 1988. Deaf in America: Voices from a Culture. Cambridge, MA: Harvard University Press.

Romanek P. Z. 2017. A prelingvális siketek nyelvelsajátítása - kitekintés. Anyanyelv-pedagógia. 10. évf. 2. szám. https://doi.org/10.21030/anyp.2017.2.1

Sandler, W., Lillo-Martin, D. 2006. Sign Language and Linguistic Universals. Cambridge: Cambridge University Press. https://doi.org/10.1017/CBO9781139163910

Stone, C. 2010. Access all areas - sign language interpreting, is it that special? Journal of Specialised Translation No. 14. 41-54.

Swabey, L., Nicodemus, B., Taylor, M. M., Gile, D. 2016. Lexical decisions and related cognitive issues in spoken and signed language interpreting. A case study of Obama's inaugural address. Interpreting Vol. 18. No. 1. 34-56. https://doi.org/10.1075/ intp.18.1.02swa

Valli, C., Lucas, C. 1992. Linguistics of American Sign Language: An Introduction. Washington D.C: Gallaudet University Press

Winston, E. A. 1989. Transliteration: What's the Message? In: Lucas, C. (ed.) The Sociolinguistics of the Deaf Community. Academic Press. 147-164. https://oi.org/10.1016/ B978-0-12-458045-9.50013-6

Winston, E., Monikowski, C. 2003. Marking Topic Boundaries in Signed Interpretation In: Metzger, M. Collins, S., Dively, V., Shaw, R. (eds) From Topic Boundaries to Omissions, New Research on Interpretation. Washington D.C.: Gallaudet University Press. 187-208. 